\title{
In situ evaluation of the ruminal and intestinal de- gradability of extruded whole horsebeans
}

\author{
P Cros , M Vernay *, R Moncoulon \\ ENSAT, Laboratoire de Zootechnie et des Productions Animales, \\ 145, avenue de Muret, 31076 Toulouse cedex, France
}

(Received 3 December 1990; accepted 1 February 1991)

\begin{abstract}
Summary - Four rumen and proximal duodenum fistulated non-lactating Holstein cows were used to determine the effect of extrusion at $120^{\circ} \mathrm{C}$ of whole horsebeans (Vicia faba cv Talo) on in vitro nitrogen $(N)$ solubility and in situ degradation of dry matter (DM) and crude protein (CP) in the rumen and intestine. Cows were fed a ration of $30 \%$ whole horsebeans (WHB) and $70 \%$ Italian rye-grass hay. The degradation of DM and CP was estimated using nylon bags suspended in the rumen for 2 , $4,7,16,24$ and $48 \mathrm{~h}$; the effective ruminal degradability of DM and CP was evaluated assuming a ruminal outflow rate of $0.06 / \mathrm{h}$. Bags incubated in the rumen for $16 \mathrm{~h}$ were introduced into the small intestine through the duodenal cannula and subsequently recovered in the feces. Extrusion of WHB reduced $\mathrm{N}$-solubility in buffer solution $(21.1$ vs $74.9 \%)$. Processing diminished the effective rumen degradability of DM (74.6 vs $80.4 \%)$ and CP $(70.2$ vs $89.2 \%)$. Meanwhile, the amounts of DM and $C P$ digested in the intestine increased: 9.6 vs $1.4 \%$ and 25.2 vs $3.0 \%$ respectively. Therefore, feeds containing extruded WHB increase the availability of dietary proteins in the intestine compared with diets containing raw WHB.
\end{abstract}

horsebean / extrusion / nitrogen-solubility / in situ degradability

Résumé - Évaluation in situ des dégradabilités ruminale et intestinale de graines de féverole extrudées. Quatre vaches laitières taries de race Holstein ont été utilisées afin de déterminer l'effet de l'extrusion à $120^{\circ} \mathrm{C}$ de la graine de féverole (Vicia faba cv Talo) sur la solubilité des protéines et la dégradabilité in situ des matières sèche (MS) et azotée (MAT) dans le rumen et l'intestin. Les animaux ont reçu une ration composée de $70 \%$ de foin de ray-grass et de $30 \%$ de graine de féverole (GF). L'extrusion de GF réduit la solubilité de l'azote $(21,1$ vs $74,9 \%)$. Les dégradabilités ruminales de la MS et des MAT ont été déterminées par la méthode des sachets nylon, les sachets étant suspendus dans le rumen pour $2,4,7,16,24$ et $48 \mathrm{~h}$. Après extrusion, les dégradabilités théoriques de la MS et des MAT dans le rumen diminuent : 74,6 vs $80,4 \%$ et 70,2 vs $89,2 \%$ respectivement (avec un taux de passage théorique des particules de 0,06/h). Les sacs incubés pendant $16 \mathrm{~h}$ dans $/ \theta$ rumen ont ensuite été introduits dans l'intestin par la canule duodénale et récupérés dans les fèces. L'extrusion accroît les disponibilités intestinales: 9,6 vs $1,4 \%$ pour la MS et 25,2 vs $3,0 \%$ pour les MAT. Le traitement de GF devrait donc se traduire par une augmentation de quantités de protéines d'origine alimentaire parvenant à l'intestin grêle.

féverole / extrusion / azote soluble / dégradabilité in situ

" Correspondence and reprints 


\section{INTRODUCTION}

An adequate protein supply to high milk producing ruminants can only be assured if enough nitrogen ( $N$ ) is available for rumen microbial crude protein (CP) synthesis in addition to dietary CP by-passing the rumen. Data on rumen $C P$ degradation have revealed that not all dietary $\mathrm{CP}$ have the same susceptibility to microbial attack and some could be protected against digestion by treatment with heat (Ahrar and Schingoethe, 1979; Stern, 1981; Thomas et al, 1987; Stutts et al, 1988). Whole horsebeans (WHB) have attracted attention in recent years as possible homegrown protein in Europe, and are particularly high in CP and carbohydrates (Cerning-Beroard and Filiatre, 1977). Limited research has shown the benefit of heating this proteaginous seed to reduce CP breakdown in the rumen (Michalet-Doreau et al, 1986) and increase small intestine availability of rumen undegraded dietary CP (McMeniman and Armstrong, 1979).

The objective of our study was to determine the effect of extrusion on WHB by measuring: i), $\mathrm{N}$-solubility in artificial saliva; and ii), degradation of dry matter (DM) and $\mathrm{CP}$ contents in nylon bags in the rumen and intestine of non-lactating Holstein cows.

\section{MATERIALS AND METHODS}

\section{Animals and feedstuffs}

Four non-lactating Holstein cows weighing 600 $\mathrm{kg}$, fitted with ruminal and proximal duodenal cannulas, were kept in individual pens on a diet consisting of $70 \%$ Italian rye-grass hay and $30 \%$ of hammermilled WHB (Vicia faba cv Talo) 2 wk prior to and throughout the experimental period. Cows were given $50 \%$ of their assigned diet at
$9.00 \mathrm{~h}$ and $50 \%$ at $17.00 \mathrm{~h}$ daily, and had free access to both feed and water. The mean daily $D M$ intake was $\approx 10 \mathrm{~kg}$.

\section{Protein sources}

The CP sources tested were WHB (Vicia Faba cv Talo), raw (R) or extruded (E) at $120^{\circ} \mathrm{C}$ (Extruder Instapro, Dievet, France); EWHB was from the same batch as the RWHB. They were ground through a 1-mm screen before use in the following experiments. Nutrient composition of dietary feedstuffs is presented in table $\mathrm{I}$.

\section{In situ incubation of protein sources}

Whole ground horsebeans $(5 \mathrm{~g})$ were placed in duplicate bags $(7 \times 11 \mathrm{~cm}$ ) of nylon cloth (Blutex T 50; Tripette et Renaud, Paris, France) with a mean pore size of $46 \mu \mathrm{m}$. For incubation in the rumen, the bags were introduced immediately before the morning feedings; they were connected by a nylon cord to the cap of the ruminal cannula and kept there for $2,4,7,16,24$ and 48 $h$. Then the bags were briefly rinsed under cold tap water to remove surface debris and machine-washed (2 $\times 5 \mathrm{~min})$; after drying the samples were weighed.

Table I. Dry matter (\%), chemical composition ( $\%$ of dry matter) of the raw and extruded whole horsebeans and the rye-grass hay.

RWHB EWHB Rye-

(10) (10) (10)

\begin{tabular}{lrrr} 
Dry matter & 87.5 & 91.5 & 91.6 \\
Crude protein & 28.8 & 29.9 & 9.4 \\
Ether extract & 2.0 & 1.7 & 1.5 \\
Neutral detergent fiber & 23.8 & 22.7 & 68.2 \\
Acid detergent fiber & 13.9 & 14.3 & 40.4 \\
Ash & 4.7 & 4.9 & 9.2 \\
\hline
\end{tabular}

RWHB: raw whole horsebeans; EWHB: extruded whole horsebeans; No of samples in parentheses. 
The effect of extrusion of WHB on the disappearance of DM and CP in the intestine was obtained by further incubation of quadruplicate bags per feedstuff per cow. After initial incubation for $16 \mathrm{~h}$ in the rumen (Michalet-Doreau et al, 1987), the bags were removed, rinsed, incubated at $40^{\circ} \mathrm{C}$ for a further $2 \mathrm{~h}$ with pepsin solution $(3 \mathrm{~g} / /$ in $0.1 \mathrm{~N} \mathrm{HCl})$, rinsed again and inserted into the small intestine through the duodenal cannula (Peyraud et al, 1988). Bags recovered from the feces were treated similarly to those removed from the rumen. Bags not recovered within $30 \mathrm{~h}$ were discarded.

\section{Biochemical analyses and calculation}

Dry matter was determined in feedstuffs $\left(105^{\circ} \mathrm{C}\right.$ overnight) and nylon bag residuals. Evaluations of fat and ash in WHB (raw and extruded), as well as in rye-grass hay were made according to the methods recommended by the AOAC (1984); neutral detergent fiber and acid detergent fiber contents of feeds were estimated by the procedure described by Van Soest (1963 $a, b ; 1965)$ and Van Soest and Wine (1967). Nitrogen (Kjeldahl) was determined both in feedstuffs and in residuals; from this, $\mathrm{CP}$ was determined as $N \times 6.25$. In addition, soluble- $N$ in each WHB protein sources was determined after extraction in artificial saliva (bicarbonatephosphate buffer; $\mathrm{pH}=6.9$ ) according to the procedure of Vérité and Demarquilly (1978).

Percentage disappearance of DM and CP from the nylon bags at each incubation time was calculated from the respective amounts remaining after incubation in the rumen. Data were fitted to the non-linear regression equation: $P=a$ $+b\left(1-e^{-c t}\right)$, where the disappearance of nutrients from the rumen, $P$, per time unit, $t$, is determined by 3 constants: a represents the rapidly soluble component, b represents the less rapidly degradable component, which disappears at the constant fractional rate, $c$, per time unit, $t$ (Ørskov and McDonald, 1979). The 3 constants and fractional outflow rate per hour, $k$, can be used to calculate effective degradability (ED) according to the equation: $E D=a+(b c) /(c+k)$. In this study solid outflow rate, $k$, was not measured but an estimated value of $0.06 / \mathrm{h}$ was used (Vérité and Peyraud, 1988).
Ruminal breakdown of DM and CP was calculated from the proportion remaining in the bags. Intestinal digestion of DM and CP was obtained by subtraction of their ruminal degradability after $16 \mathrm{~h}$ of incubation from their total digestion in the digestive tract. Differences were evaluated statistically using analysis of variance. In addition, data from the rumen nylon bag study were subjected to non-linear regression analysis and the constants, $a, b$, and $c$ were fitted by an iterative least squares procedure. Results are presented as means and standard errors.

\section{RESULTS AND DISCUSSION}

Extrusion of WHB was followed by an effective reduction of the $\mathrm{N}$-solubility in artificial saliva ( 21.1 vs $74.9 \%$ ); this finding is in agreement with those of others on the effect of heat treatment on $\mathrm{N}$-solubility (Schingoethe and Ahrar, 1979; MichaletDoreau et al, 1986; Leonard and Block, 1988).

Because the retention time of feedstuffs in the rumen is, among others, a function of amount fed, the effect of extrusion on the digestion of WHB in the rumen was examined for different ruminal incubation periods (fig 1). After $2 \mathrm{~h}$ of incubation, the disappearance of DM and CP from the rumen was significantly higher $(P<0.001)$ for RWHB than for EWHB. However, with longer incubations, the effect of extrusion gradually decreased; thus after $48 \mathrm{~h}$ in the rumen, there was no significant reduction in disappearance of DM and CP for EWHB compared to the untreated grains.

The parameters defining the equations describing the pattern of degradation of $D M$ and $C P$ as well as the EDDM and EDCP values are presented in table II. Coefficients of determination $\left(r^{2}\right)$ for disappearance of $D M$ and $C P$ were significant $(P<0.001)$. For RWHB, the amount of rapidly soluble-N (a) in the rumen was high 
(a)

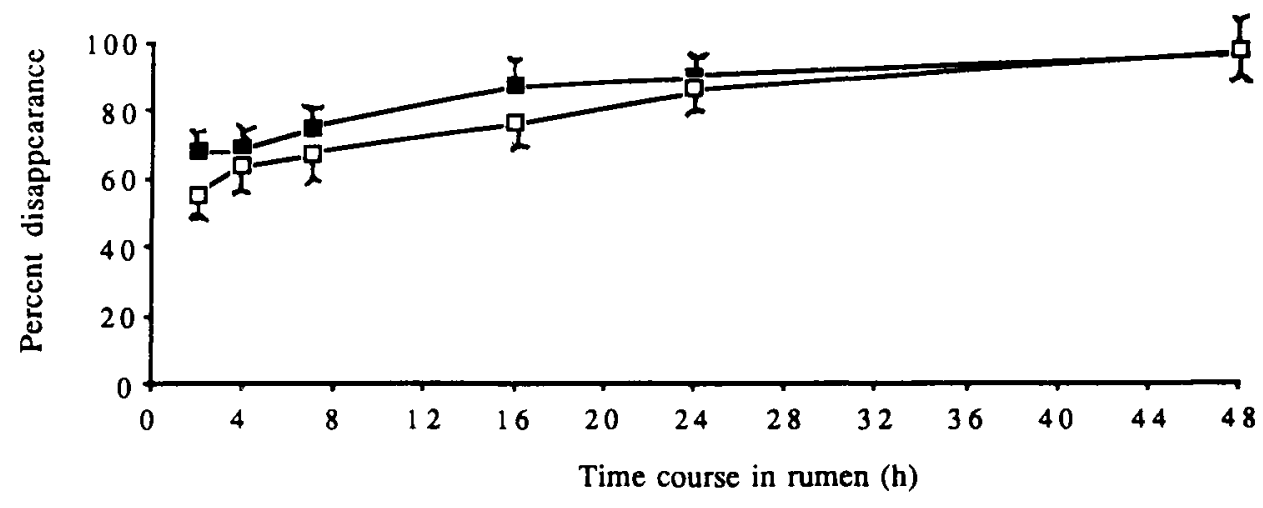

(b)

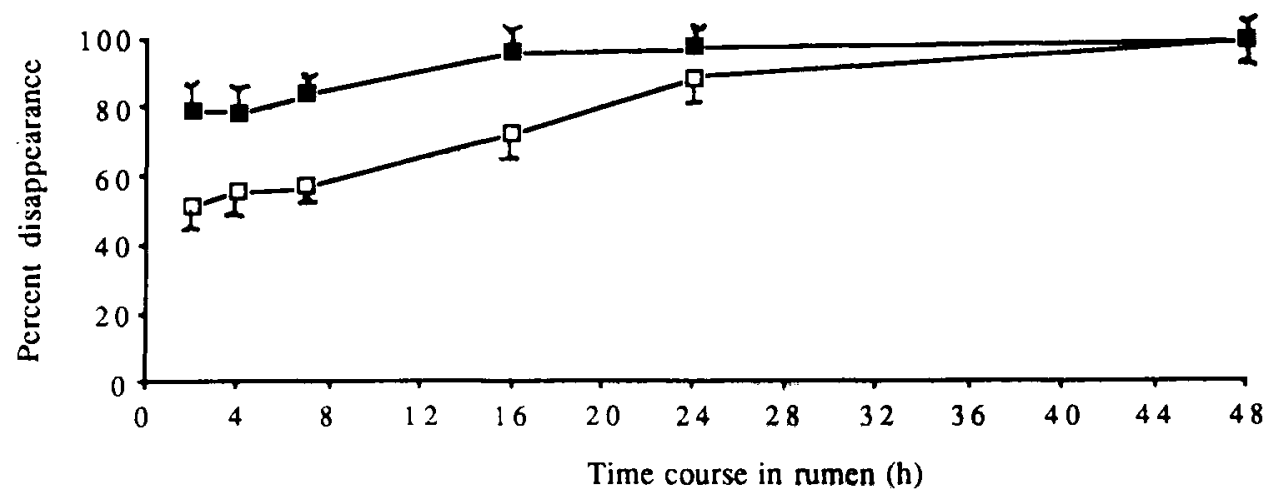

Fig 1. Effect of extrusion on percentage disappearance of dry matter (a) and crude protein (b) of whole horsebeans, raw ( $\square-\square$ ) or extruded $(\square-\square)$, from nylon bags as a function of ruminal incubation time. Each vertical bar indicates the standard error of difference between 8 means.

(67.9\%), although in agreement with buffer solubility. Likewise, Michalet-Doreau et al (1986) observed a high value of this constant in the $\mathrm{N}$-disappearance study for the Vicia faba cr Ascott (76.3\%) and a lower value $(59.8 \%)$ for Vicia faba cv Alto. The EDCP value for RWHB (89.2\%) agrees well with values obtained previously by others (Michalet-Doreau et al, 1986; Vérité and Peyraud, 1988) for the same legume seeds. Although, the general effects of treating WHB on non-linear regression parameters of $D M$ and $C P$ were similar, some differences were noted in the response to extrusion. As expected, treatment of WHB was followed by a decrease in the proportion of the rapidly degraded DM and CP fractions, $a$, and both increased the proportion and reduced the breakdown rate, $c$, of the fraction $b$, for the WHB. Consequently, EDDM and EDCP were reduced by 7.2 and $21.3 \%$ respectively. 
Table II. Effect of extrusion on non-linear parameters and effective degradability of dry matter and crude protein of the whole horsebeans.

\begin{tabular}{lcccc}
\hline & \multicolumn{3}{c}{ Dry matter } & \multicolumn{2}{c}{ Crude protein } \\
& $\begin{array}{l}\text { RWHB } \\
(48)\end{array}$ & $\begin{array}{l}\text { EWHB } \\
(48)\end{array}$ & $\begin{array}{c}\text { RWHB } \\
(48)\end{array}$ & $\begin{array}{c}\text { EWHB } \\
(48)\end{array}$ \\
\hline & & & & \\
$a(\%)$ & 60.8 & 53.2 & 67.9 & 38.5 \\
$b(\%)$ & 36.2 & 44.4 & 31.1 & 60.6 \\
$c(\%)$ & 7.1 & 5.6 & 13.1 & 6.6 \\
$r^{2}$ & 0.95 & 0.90 & 0.94 & 0.84 \\
ED (\%) & 80.4 & 74.6 & 89.2 & 70.2 \\
\hline
\end{tabular}

RWHB: raw whole horsebeans; EWHB: extruded whole horsebeans; number of samples in parentheses. $a, b, c$ $=$ non linear parameters; $E D=$ effective degradability (see $p 251$ ) $; r^{2}=$ coefficient of determination.

Total disappearance of $\mathrm{DM}$ and $\mathrm{CP}$ from the digestive tract is depicted in figure 2. The percentages observed for the whole tract digestion of DM (85.8-88.5\%) and CP (97.2-98.7\%) were high, but approximately similar to those obtained by de Boer et al (1987), with soybean meal, canola meal and fishmeal and by Arieli et al (1989) with (a)

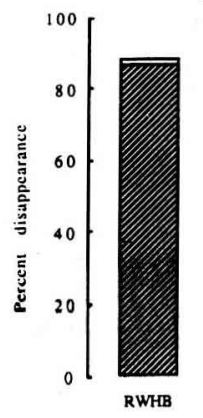

(b)

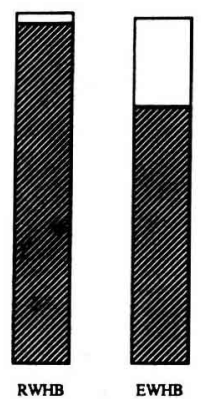

Flg 2. Effect of extrusion on relative proportions of ruminal ( of dry matter (a) and crude protein (b) from whole horsebeans. RWHB: raw whole horsebeans; EWHB: extruded whole horsebeans. whole cottonseeds. Processing of WHB significantly $(P<0.001)$ depressed DM and $C P$ digestion during rumen exposure for $16 \mathrm{~h}$, but the whole tract disappearance of these components was not significantly affected. Therefore, extrusion of WHB augmented the amount of DM and CP digested in the intestine (9.6 vs $1.4 \%$ and 25.2 vs $3.0 \%$, respectively); these results are in accordance with the linear increase in the flow of CP to the duodenum from soybean meal (Plegge et al, 1985), whole soybeans (Stern et al, 1985) and whole cottonseeds (Pena et al, 1986) heated from 115 to $149^{\circ} \mathrm{C}$. Nevertheless, in vivo studies (McMeniman and Armstrong, 1979), evaluating the incidences of heat-treatment of WHB on intestinal $C P$ availability, have yielded different results, eg processing did not significantly enhance the flow of total- $\mathrm{N}$ in the duodenum. The reason for this discrepancy between in vivo and in situ studies can be attributed to the temperature reached by the WHB $\left(105^{\circ} \mathrm{C}\right)$. Indeed, this view is supported by observations for rapeseed (Lindberg, 1984) and soybean (Mir et al, 1984) meals as well as for canola and soybeans (Deacon et al, 1988), where moderate heating of the meals and seeds did not have a pronounced effect on ruminal degradation.

Whole horsebeans CP were effectively protected from degradation in the rumen by extrusion at $120^{\circ} \mathrm{C}$ without adverse effect on CP total degradability. The increase in the supply of dietary CP to the postruminal sections as a result of extrusion could be of rapid benefit to high yield cows. Appropriate trials with these animals are now in progress.

\section{REFERENCES}

Arieli A, Ben-Moshe A, Zamwel S, Tagari H (1989) In situ evaluation of the ruminal and 
intestinal digestibility of heat-treated whole cottonseeds. J Dairy Sci 72, 1228-1233

AOAC (1984) Official Methods of Analysis. Assoc Off Anal Chem, Washington, DC, 13th edn

Ahrar M, Schingoethe DJ (1979) Heat-treated soybean meal as a protein supplement for lactating cows. J Dairy Sci 62, 932-940

de Boer G, Murphy JJ, Kennelly JJ (1987) Mobile nylon bag for estimating intestinal availability of rumen undegradable protein. $J$ Dairy Sci 70, 977-982

Cerning-Beroard J, Filiatre A (1977) Characterisation and distribution of soluble and insoluble carbohydrates in legume seeds: horsebeans, peas, lupines. In: Protein Quality from Leguminous Crops. Commission of the European Communities, EUR 5686 EN, 65-79

Deacon MA, de Boer G, Kennelly JJ (1988) Influence of jet-sploding and extrusion on ruminal and intestinal disappearance of canola and soybeans. J Dairy Sci 71, 745-753

Leonard M, Block E (1988) Effect of ration protein content and solubility on milk production of primiparous Holstein heifers. $J$ Dairy $S c i$ 77, 2709-2722

Lindberg JE (1984) Nitrogen metabolism in sheep. 2. A comparison between rumen degradability of nitrogen and organic matter in sacco and in vivo in sheep fed rations with hay, barley and various protein supplements. Swedish J Agric Res 14, 37-43

McMeniman NP, Armstrong DG (1979) The flow of amino acids into the small intestine of cattle when fed heated and unheated beans ( $V$ icia faba). J Agric Sci (Camb) 93, 181-188

Michalet-Doreau B, Doreau M, Voisin A, Bogaert C (1986) Effets de l'extrusion sur la valeur azotée des aliments pour ruminants. In : Cuisson-Extrusion. Coll No 41, Nantes. INRA Publ, Versailles 249-258

Michalet-Doreau $B$, Vérité $R$, Chapoutot $P$ (1987) Méthodologie de mesure de la dégradabilité in sacco de l'azote des aliments dans le rumen. Bull Tech CRZV Theix 69, 57

Mir Z, McLeod GK, Buchanan-Smith JG, Grieve DG, Grovum WL (1984) Methods for protecting soybean and canola proteins from degradation in the rumen. Can J Anim Sci 64, 853865
Ørskov ER, McDonald I (1979) The estimation of protein degradability in the rumen from incubation measurements weighted according to rate of passage. J Agric Sci (Camb) 92, 499-503

Pena F, Tagari H, Satter LD (1986) The effect of heat-treatment of whole cottonseed on site and extent of protein digestion in dairy cows. J Dairy Sci 62, 1423-1433

Plegge SD, Berger LL, Fahey GC Jr (1985) Effect of roasting temperature on the proportion of soybean meal nitrogen escaping degradation in the rumen. J Anim Sci61, 1211-1218

Peyraud J L, Genest-Rulquin C, Vérité R (1988) Mesure de la digestion de l'azote des aliments dans l'intestin des ruminants par la technique des sachets mobiles. Reprod Nutr Dev 28, 129-130

Schingoethe DJ, Ahrar M (1979) Protein solubility, amino acid composition and blological value of regular and heat-treated soybean and sunflower meals. J Dairy Sci 62,925-931

Stern MD (1981) Effect of heat on protein utilisation by ruminants. Feedstuffs 54, 24-27

Stern MD, Santos KA, Satter LD (1985) Protein degradation in rumen and amino acid absorption in small intestine of lactating dairy cattle fed heat-treated whole soybeans. $J$ Dairy $S C i$ $68,45-56$

Stutts JA, Nipper WA, Adkinson RW, Chandler JE, Achacoso AS (1988) Protein solubility, in vitro ammonia concentration, and in situ disappearance of extruded whole cottonseed and other protein sources. $J$ Dairy Sci 71 . 3323-3333

Thomas EE, Turnbull GW, Russell RW (1987) Effect of particle size and steam treatment of feedstuffs on rate and extent of digestion (in vitro and in situ). J Anim Sci 66, 243-249

Van Soest PJ (1943 a) Use of detergents in the analysis of fibrous feeds. I. Preparation of fiber residues of low nitrogen content. $J$ Assoc Offic Agric Chem 46, 825-829

Van Soest PJ (1963 b) Use of detergents in the analysis of fibrous feeds. II. A rapid method for the determination of fiber and lignin. $J$ Assoc Offic Agric Chem 46, 829-835

Van Soest PJ (1965) Use of detergents in the analysis of fibrous feeds. III. Study of effect of heating and drying on yield of fiber and lig- 
nin in forages. $J$ Assoc Offic Agric Chem 48, 785-790

Van Soest PJ, Wine RH (1967) Use of detergents in the analysis of fibrous feeds. IV. Determination of plant cell wall constituents. $J$ Assoc Offic Agric Chem 50, 50-55
Vérité R, Demarquilly C (1978) Qualité des matières azotées des aliments pour ruminants. In : La Vache Laitière. INRA Publ, Versailles, 143-158

Vérité R, Peyraud J L (1988) Nutrition azotée. In: Alimentation des Bovins, Ovins et Caprins. INRA Publ, Versailles, 75-93 